\title{
Seed Quality Evaluation by Tetrazolium Staining of Parkia multijuga Benth
}

\section{Marcelle Auday Costaㅁ, Elizabeth Santos Cordeiro Shimizu², Noemi Vianna Martins Leão², Hugo Alves Pinheiro ${ }^{3}$}

\author{
${ }^{1}$ Departamento de Ciências Florestais, Universidade Federal Rural da Amazônia, Belém, Brazil \\ ${ }^{2}$ Embrapa Amazônia Oriental, Belém, Brazil \\ ${ }^{3}$ Research and Technological Development of Universidade Federal Rural da Amazônia, Belém, Brazil \\ Email: marcelleauday@hotmail.com
}

How to cite this paper: Costa, M.A., Shimizu, E.S.C., Leão, N.V.M. and Pinheiro, H.A. (2018) Seed Quality Evaluation by Tetrazolium Staining of Parkia multijuga Benth. Agricultural Sciences, 9, 577-586. https://doi.org/10.4236/as.2018.95040

Received: April 7, 2018

Accepted: May 28, 2018

Published: May 31, 2018

Copyright $\odot 2018$ by authors and Scientific Research Publishing Inc. This work is licensed under the Creative Commons Attribution International License (CC BY 4.0).

http://creativecommons.org/licenses/by/4.0/

\begin{abstract}
The purpose of this study was to develop a staining pattern through tetrazolium test to evaluate seed viability of Parkia multijuga Benth (fava-arara-tucupi). The seeds were scarified, soaked into water and distilled for 48 hours for tegument removal and then immersed in a $0.05 \% ; 0.1 \%$; and $0.3 \%$ tetrazolium solution for $6 ; 18$ and 24 hours at $35^{\circ} \mathrm{C}$, in the dark. The evaluation was performed on the basis of stain intensity and aspect of the tissues. Based on color patterns, the seed images were classified in eight viability classes. Those results were compared with the germination test in a laboratory. The treatment in concentration of $0.1 \%$ for 6 hours was considered adequate for the specie, considering the adequate staining and time for analysis.
\end{abstract}

\section{Keywords}

Forest Seeds, Fava-Arara-Tucupi, Viability, Amazon

\section{Introduction}

Parkia multijuga also known fava-arara-tucupi or pinho-cuiabano is a woody specie from the Central Amazon. It is found in both solid ground and high floodplain argillic soil [1]. It presents a moderate annual production of viable seeds [2] with physical dormancy imposed by a hard and waterproof tegument [1] [3]. However, observation of its seed quality must be considered. [4] shows that only 35 days are required to obtain the final count of the germination test for this specie, which can be regarded as a long period. That result influences on decision making concerning the use of seeds for storage, commercialization, and 
seedling production.

The use of high quality seeds which is essential for the success of the introduction of any culture and forest operations also depends on seedling quality and the consequent success of a reforestation program. To achieve this, there are internal quality control programs developed by seed companies that aim for fast and efficient tests to determine the viability of seed lots.

Tetrazolium test permits to make a fast viability determination of dormant, recalcitrant seeds, and of those that germinate slowly during routine tests [5]. It also evaluates seed vigor and contributes to the identification of factors that influence seed quality such as mechanical damages, drying, insects, and deterioration caused by humidity [6].

The data obtained through this test can be used to establish basis for commercialization, determination of harvest point and quality control during storage [7]. The test permits a rapid viability determination, in less than 24 hours [8].

This method is widely used for agricultural species, and has been improved for forest plant species and been used mainly for seed tests of Mauritia flexuosa [9], Senna multijuga and Senna macranthera [10], Peltophorum dubium [11], Eremanthus elaenagnus Less (Mart. Ex. DC.) Schultz-Bip, Eremanthus glomerulantus Less and Eremanthus incanus [12] and Tabebuia aurea [13].

Pre-soaking and incubation time, concentration of tetrazolium salt solution and the adequate test evaluation are fundamental to obtain reliable results concerning viability and vigor [11] [14]. To facilitate absorbance of tetrazolium salt solution, pre-soaking is necessary and recommended for some species. If the seed coat prevents soaking the seed may require manual scarification or perforation [5]. The efficiency of this test to evaluate seed viability depends on the method adapted for each species to define the appropriate conditions for hydration, preparation, staining and seed evaluation [15].

The objective of the study was to establish a proper procedure for conducting tetrazolium test in seeds of Parkia multijuga.

\section{Material and Methods}

The Parkia multijuga seeds used for this experiment came from 12 matrices collected in the Alto Moju Region, State of Pará, on September 2013. During processing, immature, decaying and damaged seeds were removed. The seeds were taken to the Laboratório de Sementes Florestais (LASF) (Forest Seed Laboratory) of Embrapa Amazônia Oriental, Belém-PA, placed in paper bags, stored in cold chambers at $0^{\circ} \mathrm{C}$ to $5^{\circ} \mathrm{C}$ and $70 \%$ relative humidity.

The seeds were scarified with No.180 sandpaper on the other side to the hilum to facilitate the tegument removal. Afterwards, the seeds were immersed in distilled water sufficient for 25 seeds and kept at room temperature for 48 hours, with water replacements. Next, the seed teguments were removed and the embryos placed in tetrazolium solution pH 6.5 [5]. One hundred (100) seeds were used, subdivided into for repetitions containing 25 seeds each. 


\subsection{Tetrazolium Test}

One hundred (100) seeds were used for the tetrazolium test subdivided into four repetitions of 25 each. The concentrations of the tested solution were $0.05 \%$, $0.1 \%$ and $0.3 \%$, where the embryos were immersed into $400 \mathrm{~mL}$ of solution for each repetition, kept in disposable plastic cups at $35^{\circ} \mathrm{C}$, in the dark for 6,18 and 24 hours for the staining process [5] [16].

After those periods the seeds were removed from the solutions and washed into distilled water and kept submerged until evaluation. The embryos were sectioned longitudinally using a stylus, among the cotyledons, evaluating staining intensity, presence of white milky areas, aspects of the tissues and staining location in relation to the cotyledons and embryonic axis.

To interpret the results, each embryo was analyzed and classified separately according to staining, forming different viability classes. To characterize the levels of viability, it was observed the presence and location of damage in the embryonic structures in each class.

Differentiation of tissue colors was done according to patterns proposed by [11] [17] [18] [19] [20] for several agricultural and forest species, after that, the eight classes of viability were determined. The viability was expressed in percentages of viable seeds in the different classes. The tetrazolium test result was compared with the germination test.

\subsection{Germination Test}

Due to the tegument hardness, the seeds were subjected to pre-germination treatment to break their dormancy. The procedure used was scarification with No. 180 sandpaper. Immediately after, the seeds were submerged into distilled water for 48 hours. Subsequently, they were washed with sodium hypochlorite solution at $1 \%$ for 5 minutes, and placed to germinate in "Germitest" paper towel moistened to 2.5 times the paper weight following procedures set by the Rules for Seed Analyses [5]. Sixty (60) seeds were distributed in four repetitions of 15 seeds each. Due to the size of the seeds, each repetition was subdivided into two samples, with eight and seven seeds respectively.

The test was conducted at constant temperature of $30^{\circ} \mathrm{C}$ and 12 hours of light using 20W fluorescent lamps in BOD. The evaluations were performed daily until stabilization of the germination process, being considered germinated those seeds with radicle protrusion measuring approximately $5 \mathrm{~mm}$.

\subsection{Statistical Analysis}

The experiment was conducted in a completely randomized design with a $3 \times 3$ factorial arrangement (three concentrations in three times) with four repetitions.

The data obtained from the tetrazolium and germination tests were transformed in arcsen. in (1), and subjected to analysis of variance. The means compared by the Dunnet test was at 5\% probability, using the BioEstat software [21]. 


$$
\sin \sqrt{x / 100}
$$

\section{Results}

During the tests the seeds from P. multijuga lot had $10 \%$ water content. They also presented $90 \%$ of germination, and $80 \%$ of them formed normal seedlings. The results expressed the viability of the seeds in concentrations $0.05 \%$ for 6 and 24 hours and $0.1 \%$ and $0.3 \%$ for 6,18 and 24 hours, because they did not differ significantly from the germination test (Table 1). However, when the seeds were submerged in $0.05 \%$ solution for 18 hours, there was a significant difference $(\mathrm{p} \leq$ 0.05 ) from the germination test in the intense-red staining of the embryonic axis indicating tissue decay. For this concentration, the viability of the seeds was overestimated by the tetrazolium test, probably caused by microorganisms found in the lot, considering that the tetrazolium test does not detect the presence of pathogens that may cause a decline in the germination test [22].

The results from the tetrazolium test are presented on Table 1 and compared with the percentage of germination.

Means followed by the same capital letter in the columns do not differ between themselves by the Dunnete test $(\mathrm{p}<0.05)$.

The embryo classification was divided in eight classes, between viable and unviable seeds, based on their staining intensity, aspect and strength of tissues. They are presented on Figure 1 following the denominations below:

Class 1 (Viable): cotyledons with light pink staining and /or unstained. Tissues with normal and firm aspect.

Class 2 (Viable): light or unstained cotyledons, and embryonic axis with light pink stains. Tissues with normal and firm aspect.

Class 3 (Viable): embryonic axis and cotyledons with dark pink staining. Completely stained cotyledons. Tissues with normal and firm aspect.

Class 4 (Viable): more than 50\% of cotyledons stained, and embryonic axis with pink stain. Tissues with normal and firm aspect.

Table 1. Test results of tetrazolium and germination in seeds of $P$. multijuga.

\begin{tabular}{|c|c|c|}
\hline \multicolumn{2}{|c|}{ Tetrazolium } & \multirow{2}{*}{ Viable seeds (\%) } \\
\hline Concentration (\%) & Time (hours) & \\
\hline \multirow{3}{*}{0.05} & 6 & $90 \mathrm{~A}$ \\
\hline & 18 & $69 \mathrm{~B}$ \\
\hline & 24 & $81 \mathrm{~A}$ \\
\hline \multirow{3}{*}{0.1} & 6 & $87 \mathrm{~A}$ \\
\hline & 18 & $90 \mathrm{~A}$ \\
\hline & 24 & $90 \mathrm{~A}$ \\
\hline \multirow{3}{*}{0.3} & 6 & $90 \mathrm{~A}$ \\
\hline & 18 & $85 \mathrm{~A}$ \\
\hline & 24 & $84 \mathrm{~A}$ \\
\hline Germination test & & $90 \mathrm{~A}$ \\
\hline
\end{tabular}



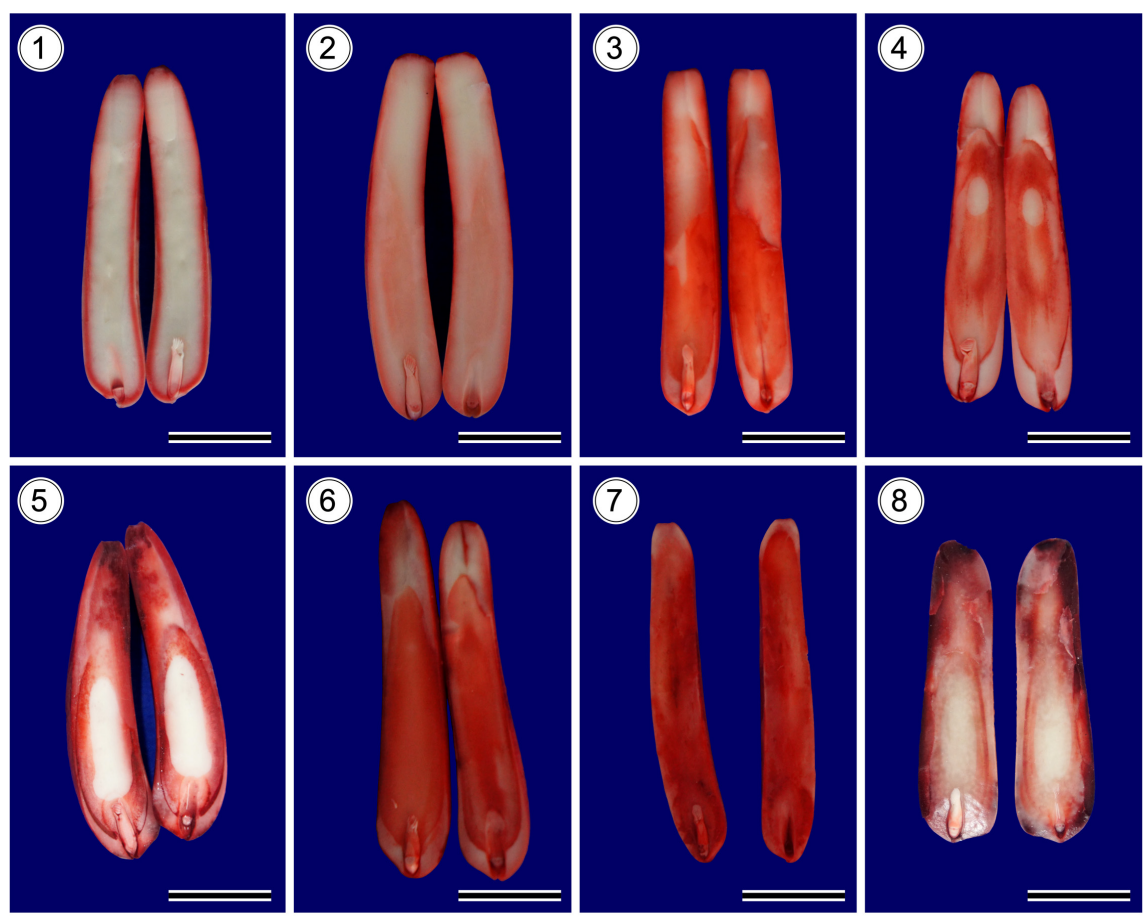

Figure 1 . Classes 1 to 8 for the determination of viability of $P$. multijuga seed by tetrazolium test. The bars represent $20 \mathrm{~mm}$.

Class 5 (Viable): cotyledon and embryonic axis with pink or red staining, with light or white stains in the center of cotyledons. Tissues with normal and firm aspect.

Class 6 (Viable): cotyledon and embryonic axis with red staining. Tissues normally firm.

Class 7 (Non-Viable): cotyledons with bright red to brown staining and embryonic axis with bright red staining. Tissues in decay.

Class 8 (Non-Viable): cotyledons with bright red to brown staining and unstained embryonic axis.

\section{Discussion}

During the tests, the P. multijuga lot under study presented $10 \%$ water content, while [23], analyzing seeds from Parkia velutina lot found humidity degree of 11.3\%. [24] states that water contents below 13\% do not jeopardize the seed quality, allowing its storage for longer periods.

$P$. multijuga seed tegument is very hard, which makes the intumescence process difficult. Nevertheless, the seeds were subjected to scarification, imbibition and removal of tegument, thus favoring penetration of tetrazolium solution and allowing a more uniform coloration of the structures, avoiding mechanical damages. This method was considered efficient because it does not cause mechanical damage to the embryo as shown on Figure 2.

Seeds with thick and hard teguments must be removed before staining [17], 


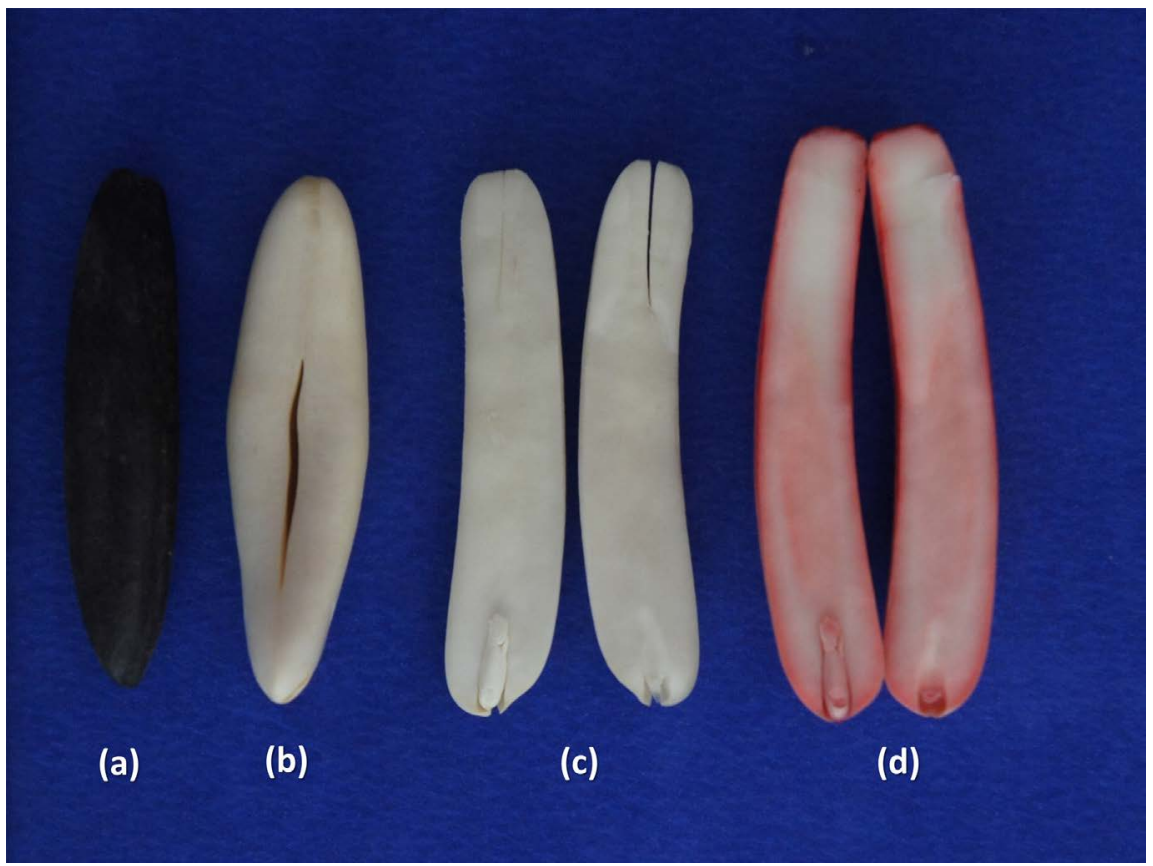

Figure 2. Steps of seed treatment of $P$. multijuga to facilitate salt penetration of tetrazolium. (a) Seed without treatment with hard tegument; (b) Seed without tegument, after 48 $\mathrm{h}$ of imbibition in distilled water; (c) Seed split longitudinally, exposure of the embryo; (d) Seed stained with tetrazolium salt, viable seed.

therefore, tegument removal has been suggested for several forest species, such as Parkia velutina Benoist [23], Melanoxylon brauna Schot [20], Schizolobium amazonicum [25], Poecilanthe parviflora Bentham [6], Anadenanthera peregrina [14], Gleditschia amorphoides [26].

Studies with forest and fruit tree species show that the period for germination standard test may be long, as is the case of Astrocaryum tucuma Mart. that may take as long as 180 days to germinate. [4]. [11] when analyzing Tabebuia serratifolia and Tabebuia impetiginosa seeds observed that the germination test finished in 28 days, however when the same seeds were submitted to tetrazolium test, the result took one day.

Tetrazolium test must represent the germination test, giving an approximate idea of germination for a certain lot of seeds [27]. The choice of an adequate methodology to use the tetrazolium test should be based on the facility to differentiate viable from non-viable tissues and its capability to differentiate lots with distinctive physiological quality [28].

The seeds from classes 1 to 6 presented a uniform pink and/or red staining and normal, healthy and firm aspect (Figure 1), staining was uniform indicating live and vigorous tissues. However, for classes 7 and 8 the cotyledon stains were intense red to brown, and embryonic axis intense red or non-stained. According to [29], vigorous tissues tend to gradually and uniformly change color and, when embedded they become turgid. The occurrence of intense red is a characteristic of decaying tissues that permit a greater diffusion of tetrazolium solution, 
through compromised cell membranes.

The absence of stains in white or yellowish flaccid tissues was observed in some studies with forest species such as: Parkia velutina Benoist [23], Peltophorum dubium [11], Copaifera langsdorffii and Schizolobium parahyba [30], Gleditschia amorphoides Taub [25]. This pattern was not found in the lot of this study. It may occur, however it depends on how the seeds are stored and/or some situation of stress. White indicates dead tissues, without the necessary enzyme activity for production of de triphenyl formazan [16].

According to [11] during the tetrazolium test only the embryo is evaluated. It does not consider the influence of external structures of the seeds in germination test results, such as possible infestations with pathogens in the lots. Germination and tetrazolium test results should be close, with a difference margin of $5 \%$ between them [10].

As for staining in the embryonic axis of the seeds in different concentrations analyzed, stains were pink or red in vigorous tissues for concentrations of $0.05 \%$ (6 and 24 hours), and $0.3 \%$ (6.18 and 24 hours), which allowed a sharpen staining of the embryos, when compared to concentration of $0.05 \%$ ( 18 hours), although for this concentration, the cotyledons produced a more intense stain showing an aspect of decay (Table 1 ).

Studies done by [13] showed that tetrazolium test was efficient for estimating the viability of $S$. gardneriana seeds for concentration of $0.075 \%$ for six hours, at $35^{\circ} \mathrm{C}$ as the best condition. In Araucaria angustifolia seeds, the test efficiency and rapidity occurs through embryo excision and direct immersion in tetrazolium solution, in the following combinations of concentration, period and temperature: $0.5 \%$ for 2 hours at $30^{\circ} \mathrm{C}, 0.075 \%$ for 4 hours at $40^{\circ} \mathrm{C}$ or $0.5 \%$ for 2 hours at $40^{\circ} \mathrm{C}$, allowing classification of seeds into two distinct groups, viable and non-viable groups [31].

Among the viability results for $P$. multijuga seeds, the ones considered the most suitable for germination test was the concentration of $0.05 \%$ for 6 and 24 hours with equivalence in the outcomes of this treatment with the germination test in terms of adequate embryo staining for better visualization. However, for a 6 hour period, the treatment resulted in a very poor visualization pattern, not adequate for a good interpretation of the test, which can lead to error during the analysis. For the 24 hour period, the staining pattern was adequate, however considering that one of the principles of the tetrazolium test is to verify the viability of seed lots in the shortest time possible, this treatment was not considered the ideal test.

The attainment of a uniform and adequate staining for a safe and efficient interpretation is also a factor of great importance for the successful use of the test on a particular species [32]. However, the concentration of $0.1 \%$ for 6 hours, provided a good staining for visualization of embryo viability in Parkia multijuga seeds combining these two very important characteristics in tetrazolium test, saving of test reagent and speed of analysis. 


\section{Conclusion}

Concentration of $0.1 \%$ of tetrazolium solution for 6 hours permits to evaluate the quality $P$. multijuga seed lots.

\section{Acknowledgements}

Conselho Nacional de Desenvolvimento Científico e Tecnológico (Brazilian National Council for Scientific and Technological Development)-CNPq for the research grant and Embrapa Amazônia Oriental for use of its facilities and support that permitted the elaboration of this study.

\section{References}

[1] Hopkins, H.C. (1986) Parkia (Leguminosae: Mimosoideae). New York Botanical Garden, New York, Monografia, Flora Neotrópica, 93-98.

[2] Lorenzi, H. (1992) Árvores brasileiras: manual de identificação e cultivo de plantas arbóreas nativas do Brasil. Ed. Plantarium, Nova Odessa.

[3] Santos, K.D.G. (2012) Germinação e desenvolvimento inicial de Dipteryxalata Vogel e Parkia platycephala Benth. (Fabaceae) sob condições de campo. Dissertation, Universidade Federal do Tocantins, Porto Nacional.

[4] Brasil. Ministério da Agricultura, Pecuária e Abastecimento (2013) Instruções para análise de sementes. MAPA, Brasília, DF.

http://www.agricultura.gov.br/arq_editor/file/Laboratorio/Sementes/FLORESTAL_ documento_pdf.pdf

[5] Brasil. Ministério da Agricultura, Pecuária e Abastecimento (2009) Regras para análise de sementes. Ministério da Agricultura, Pecuária e Abastecimento. Secretaria de Defesa Agropecuária. MAPA/ACS, Brasília. http://www.agricultura.gov.br/arq_editor/file/2946_regras_analise_sementes.pdf.

[6] Valadares, J., Paula, R.C. de. and Vitti Môro, F. (2009) Germinação, desenvolvimento de plântulas e teste de tetrazólio em Poecilanthe parviflora Bentham (Fabaceae-Faboideae). Científica, Jaboticabal, 37, 39-47. http://dx.doi.org/10.15361/1984-5529.2009v37n1p39+-+47

[7] Marcos-Filho, J., Cícero, S.M. and Silva, W.R. (1987) Avaliação da qualidade fisiológica das sementes. FEALQ, Piracicaba.

[8] Gimenez, J.I., Ferreira, G. and Cavariani, C. (2014) Tetrazolium Test for Assessment of Seed Viability of Atemoya (Annona cherimola Mill. x A. squamosa L). Journal of Seed Science, 36, 357-361. http://www.scielo.br/pdf/jss/v36n3/12.pdf https://doi.org/10.1590/2317-1545v36n31004

[9] Spera, M.R.N., Cunha, R. and Teixeira, J.B. (2001) Quebra de dormência, viabilidade e conservação de sementes de buriti (Mauritia flexuosa). Pesquisa Agropecuária Brasileira, 36, 1567-1572. http://dx.doi.org/10.1590/S0100-204X2001001200015

[10] Ferreira, R.A., Davide, A.C. and Motta, M.S. (2004) Vigor e viabilidade de sementes de Senna multijuga (Rich.) Irwin et Barn. e Senna macranthera (Collad.) Irwin et Barn. num banco de sementes em solo de viveiro. Revista Brasileira de Sementes, 26, 24-31. http://dx.doi.org/10.1590/S0101-31222004000100004

[11] Oliveira, L.M.de., Carvalho, M.L.M.de. and Davide, A.C. (2005) Teste de tetrazólio 
para avaliação da qualidade de sementes de Peltophorum dubium (sprengel) taubert, leguminosae-caesalpinioideae. CERNE, 11, 159-166.

http://www.redalyc.org/articulo.oa?id=74411206

[12] Velten, S.B. and Garcia, Q.S. (2005) Efeitos da luz e da temperatura na germinação de sementes de Eremanthus (Asteraceae), ocorrentes na Serra do Cipó, MG, Brasil. Acta Botanica Brasilica, 19, 753-761. http://dx.doi.org/10.1590/S0102-33062005000400010

[13] Oliveira, A.K.M., Schedler, E.D. and Favero, S. (2006) Caracterização morfológica, viabilidade e vigor de sementes de Tabebuia aurea (Silva Manso) Benth. \& Hook. f. ex. S. Moore. Revista Árvore, Viçosa-MG, 30, 25-32.

http://www.scielo.br/pdf/rarv/v30n1/28505.pdf https://doi.org/10.1590/S0100-67622006000100004

[14] Pinho, D.S., Borges, E.E. de L., Carvalho, A.P.V. and Corte, V.B. (2011) Adequação da metodologia do teste de tetrazólio para avaliação da viabilidade de sementes de angico. Pesquisa Florestal Brasileira, Colombo, 31, 269-272.

http://dx.doi: 10.4336/2011.pfb.31.67.269

[15] Pinto, T.L.F., Brancalion, P.H.S., Novembre, A.D.L.C. and Cicero, S.M. (2008) Avaliação da viabilidade de sementes de coração-de-negro (Poecilanthe) Benth.Fabaceae-Faboideae) pelo teste de tetrazólio. Revista Brasileira de Sementes, 30, 208-214. http://dx.doi.org/10.1590/S0101-31222008000100026

[16] França Neto, J.B., Krzyzanowski, F.C. and Costa, N.P. (1998) O teste de tetrazólio em sementes de soja. Embrapa, Londrina. http://www.agrolink.com.br/downloads/TRETRAZ\%C3\%93LIO.pdf

[17] Grabe, D.F. (1976) Manual do teste de tetrazólio em sementes. AGIPLAN, Brasília.

[18] International Seed Testing Association ISTA (1993) International Rules for Seed Testing. Seed Science and Technology, 21, 296.

[19] Moore, R.P. (1972) Interpretation of Color Differences in Tetrazolium Testing. Seed Technologist News, 44, 22-24.

[20] Corte, V.B., Borges, E.E.L. and Pereira, B.L.C. (2010) Adequação da metodologia do teste de tetrazólio para a avaliação da viabilidade de sementes de Melanoxylon brauna Schot. Cerne, 16, 415-421. https://doi.org/10.1590/S0104-77602010000300018

[21] Ayres, M., Ayres Júnior, M., Ayres, D. and Santos, A.L. (2007) BioEstat 5.0: Aplicações estatísticas nas áreas das ciências biológicas e médicas. MCT, IDSM, CNPq, Belém.

[22] Seneewong, A., Baskin, C.C. and Batson Junior, W.E. (1991) The Relationship between Internal Disease Organisms and Germination of Gin Run Cottonseed (Gossypium hirsutum, L.). Journal of Seed Technology, 15, 91-96.

[23] Mendes, A.M.S., Bastos, A.A. and Melo, M.G.G. (2009) Padronização do teste de tetrazólio em sementes de Parkia velutina Benoist (Leguminosae-Mimosoideae). Acta Amazonica, 39, 823-828. https://doi.org/10.1590/S0044-59672009000400010

[24] Medeiros, A.C.S. (2001) Armazenamento de sementes de espécies florestais nativas. Documentos 66, Embrapa Florestas, Colombo. http://ainfo.cnptia.embrapa.br/digital/bitstream/item/17076/1/doc66.PDF

[25] Shimizu, E.S.C., Pinheiro, H.A., Costa, M.A. and Santos Filho, B.G. (2011) Aspectos fisiológicos da germinação e da qualidade de plântulas de Schizolobium amazonicum em resposta à escarificação das sementes em lixa e água quente. Revista Arvore, 35, 791-800. 
http://www.scielo.br/readcube/epdf.php?doi=10.1590/S0100-67622011000500004\& pid=S0100-67622011000500004\&pdf_path=rarv/v35n4/a04v35n4.pdf\&lang=pt

[26] Fogaça, C.A., Malavasi, M.M., Zucareli, C. and Malavasi, U.C. (2006) Aplicação do teste de tetrazólio em sementes de Gleditschia amorphoiides Taub. Caesalpinaceae. Revista Brasileira de Sementes, 28, 101-107.

[27] Lazarotto, M., Piveta, G., Muniz, M.F.B. and Reiniger, L.R.S. (2011) Adequação do teste de tetrazólio para avaliação da qualidade de sementes de Ceiba speciosa. Semina: Ciências Agrárias, 32, 1243-1250.

http://www.uel.br/revistas/uel/index.php/semagrarias/article/view/4771 https://doi.org/10.5433/1679-0359.2011v32n4p1243

[28] Krzyzanowski, F.C., Vieira, R.D. and França Neto, J.B. (1999) Vigor de sementes: Conceitos e testes. ABRATES, Londrina.

[29] Moore, R.P. (1985) Handbook on Tetrazolium Testing. International Seed Testing Association, Zurich.

[30] Fogaça, C.A., Krohn, N.G., Souza, M.A. and Paula, R.C. (2011) Teste de tetrazólio em sementes de Copaifera langsdorffii e Schizolobium parahyba. Revista Floresta, Curitiba, 41, 895-904.

[31] Silva, B.A., Nogueira, J.L., Vieira, E.S.N. and Panobianco, M. (2016) Critérios para condução do teste de tetrazólio em sementes de araucária. Pesquisa Agropecuária Brasileira, 51, 61-68. https://doi.org/10.1590/S0100-204X2016000100008

[32] Bhering, M.C., Dias, D.C.F.S. and Barros, D.I. (2005) Adequação da Metodologia do Teste de Tetrazólio para Avaliação da Qualidade Fisiológica de Sementes de Melancia. Revista Brasileira de Sementes, 27, 176-182.

http://www.scielo.br/pdf/\%0D/rbs/v27n1/25196.pdf https://doi.org/10.1590/S0101-31222005000100022 